\title{
Artelogie
}

Recherche sur les arts, le patrimoine et la littérature de l'Amérique latine

$7 \mid 2015$

Photographie contemporaine en Amérique latine

\section{Imágenes de la postdictadura en Argentina}

\section{Cora Gamarnik}

\section{OpenEdition \\ Journals}

\section{Edición electrónica}

URL: https://journals.openedition.org/artelogie/1072

DOI: 10.4000/artelogie.1072

ISSN: 2115-6395

Editor

Association ESCAL

\section{Referencia electrónica}

Cora Gamarnik, «Imágenes de la postdictadura en Argentina», Artelogie [En línea], 7 | 2015, Publicado el 15 abril 2015, consultado el 11 abril 2022. URL: http://journals.openedition.org/artelogie/1072 ; DOI: https://doi.org/10.4000/artelogie.1072

Este documento fue generado automáticamente el 11 abril 2022.

Association ESCAL 


\title{
Imágenes de la postdictadura en Argentina
}

\author{
Cora Gamarnik
}

\author{
"Hacer obra de historiador [...] significa \\ apoderarse de un recuerdo, tal como surge en el \\ instante del peligro". \\ Walter Benjamin, Sobre el concepto de historia, \\ Obras, libro 1, volumen 2, Madrid, 2008. \\ "Descubrir entonces en el análisis del pequeño \\ momento singular el cristal del acontecer total". \\ Walter Benjamin, Libro de los Pasajes (1927-1940),
} Madrid, 2005.

\section{3: campaña electoral y retorno a la democracia}

1 El inicio de la democracia en 1983 significó una bisagra en la historia argentina reciente. En octubre de ese año, se desarrollaron las primeras elecciones presidenciales democráticas luego de siete años de terrorismo de Estado que dejaron un saldo de miles de desaparecidos, muertos, exiliados y un país económicamente devastado. La derrota de las tropas argentinas en la guerra de Malvinas, en junio de 1982, había acelerado el final de la dictadura militar y abierto nuevas y profundas heridas. Raúl Alfonsín, candidato de la Unión Cívica Radical (UCR), ganó esas primeras elecciones presidenciales y se inició un período que politólogos e historiadores denominaron de "transición a la democracia" ${ }^{1}$, atravesado por una atmósfera cultural y política en ebullición en donde se entremezclaban las demandas sociales emergentes, en particular las vinculadas al movimiento de derechos humanos, con presiones múltiples, provenientes del poder militar y de los organismos financieros internacionales. En esos primeros años de la postdictadura la corporación militar buscó e implementó mecanismos para condicionar a la futura democracia 
2 En el país, las manifestaciones se multiplicaban, las calles eran una fiesta y los fotógrafos lo registraban. Actos políticos, artísticos, culturales, marchas en defensa de los derechos humanos, protestas sindicales y vecinales reunían a centenares de miles de personas. Los mismos reporteros gráficos que habían puesto el cuerpo para fotografiar los diversos acontecimientos y manifestaciones de 1982 y 1983, que se habían acostumbrado a fotografiar entre gases lacrimógenos y balas de goma, estaban ahora registrando la recuperación del espacio público.

3 Para los fotógrafos, 1983 fue un año de intenso trabajo y mucho reacomodamiento laboral. Abrían y cerraban medios gráficos, se ampliaban y diversificaban las ofertas laborales y algunos de ellos comenzaron a generar proyectos individuales y colectivos al margen de los medios. En medio de la campaña electoral los fotógrafos organizaron la Tercera Muestra de Periodismo Gráfico para ser expuesta antes de las elecciones, pero no pudo inaugurarse hasta ya instalado el gobierno electo ${ }^{2}$. El material a exhibirse fue considerado "atentatorio contra las fuerzas de seguridad". Faltaban días para dejar el poder y funcionarios militares impedían su realización. Finalmente el 17 de diciembre de 1983 se inauguró, esta vez en democracia, la Tercera Muestra de Periodismo Gráfico Argentino. En la tapa del catálogo aparecían tres fotos: dos manifestantes empuñando una valla contra la Casa Rosada, tomada en la Marcha de la Multipartidaria el 16 de diciembre de 1982 por Jorge Rilo, una madre y una hija con pañuelos blancos en señal de grito de lucha por el esposo/padre desaparecido, de Adriana Lestido, y por último, una imagen donde se ve un cóndor enmarcando al Congreso de la Nación, de Daniel Merle.

Figura 1: Tapa del catálogo de la Tercer Muestra de Periodismo Gráfico Argentino. Diciembre 1983

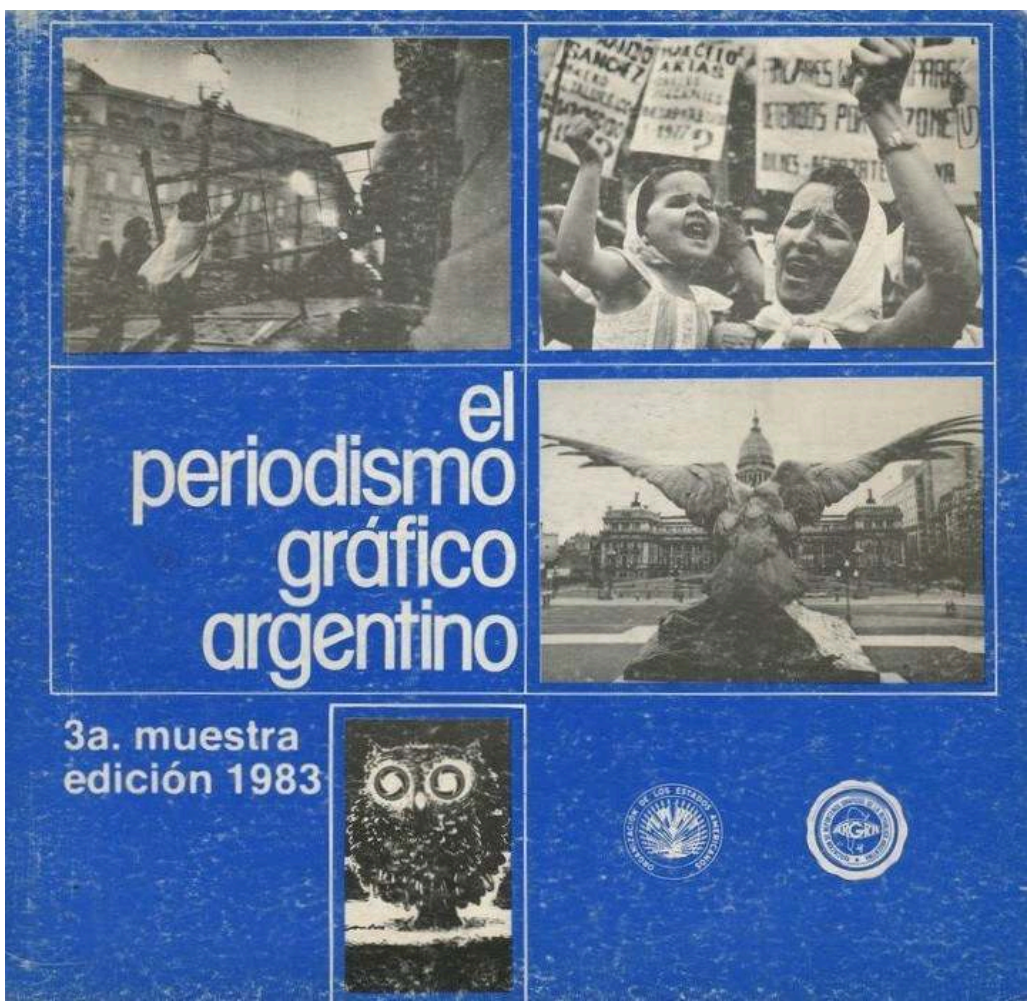

El final de la dictadura, la lucha por los derechos humanos y la naciente democracia aún amenazada era el recorrido propuesto en esta selección. Participaron en esta tercera 
muestra en total 107 fotógrafos con 321 fotografías. 19 fotógrafos más que en 1982 y 37 más que en 1981.

En esta exposición se dispuso la organización por temas en vez de por fotógrafo como había sido en años anteriores. Los ejes con los cuales se agruparon las imágenes fueron: Elecciones, Derechos Humanos, Política, Personajes, Información general, Deportes y Misceláneas. Cada autor debía sugerir al dorso de su imagen en qué sección debería colgarse. También se habilitó una sección para fotografías que enviaban reporteros argentinos que vivían en el exterior. El recorrido propuesto cuando uno entraba a la exposición comenzaba por las fotos de derechos humanos y terminaba por las imágenes vinculadas a la campaña electoral. El camino mismo narraba una historia.

6 Esta tercera exposición logró superar a las dos anteriores organizativamente, en afluencia de público y en cuanto a impacto visual. La muestra tuvo una trascendencia política y social que instaló a los reporteros gráficos como un actor central en el relato periodístico de los acontecimientos de finales de la dictadura. En cuanto a las fotos allí expuestas, se podía ver el renacer de la vida política, a las Madres de Plaza de Mayo en acciones de lucha y resistencia, a los nuevos actores políticos que se presentaban a elecciones, fotos de denuncia del aparato militar y escenas de pobreza, entre otras.

Figura 2: Fotografía expuesta en la Tercer Muestra de Periodismo Gráfico Argentino. Diciembre 1983

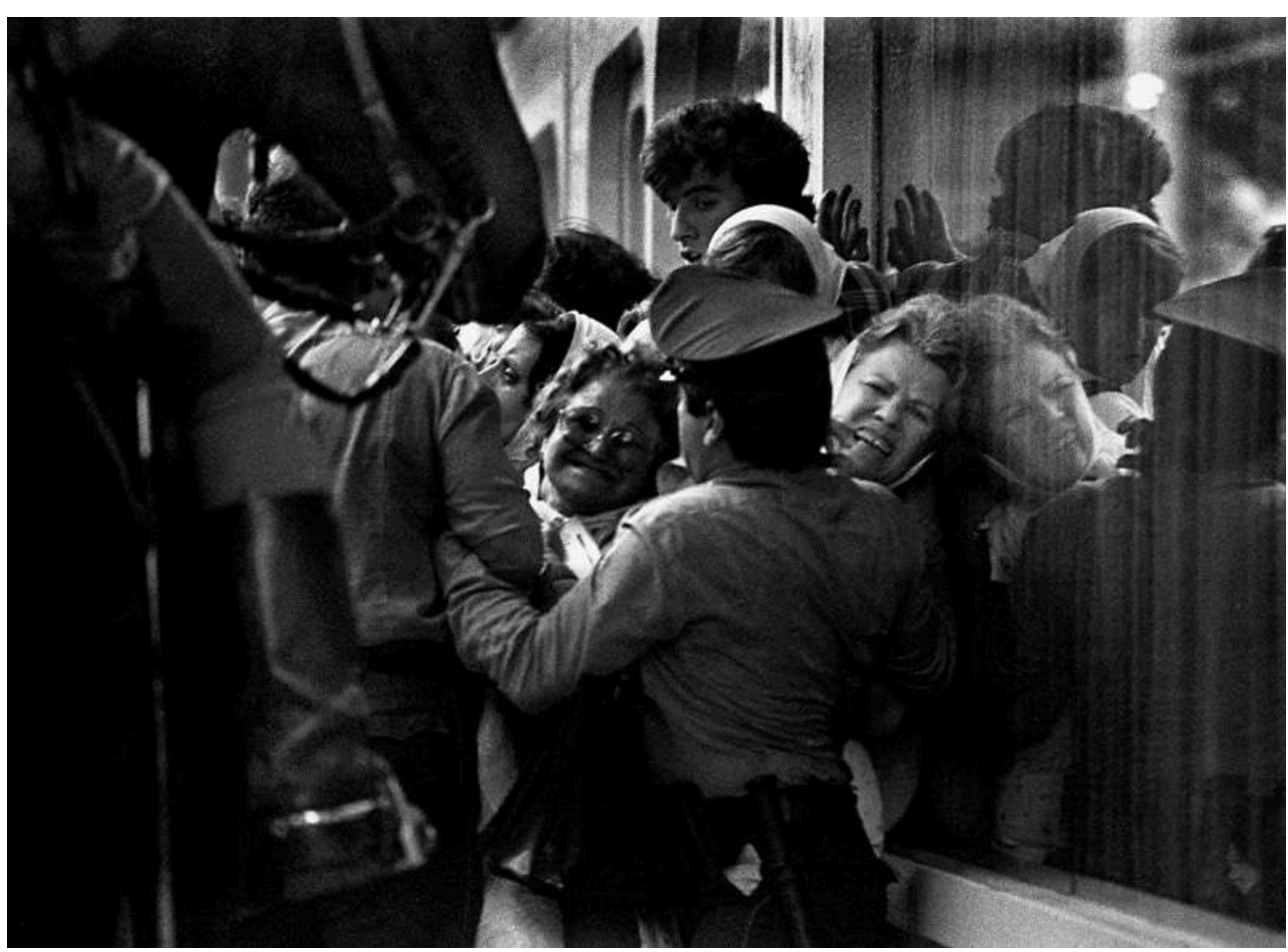

Autor: Daniel García 
Figura 3: Fotografía expuesta en la Tercer Muestra de Periodismo Gráfico Argentino. Diciembre 1983

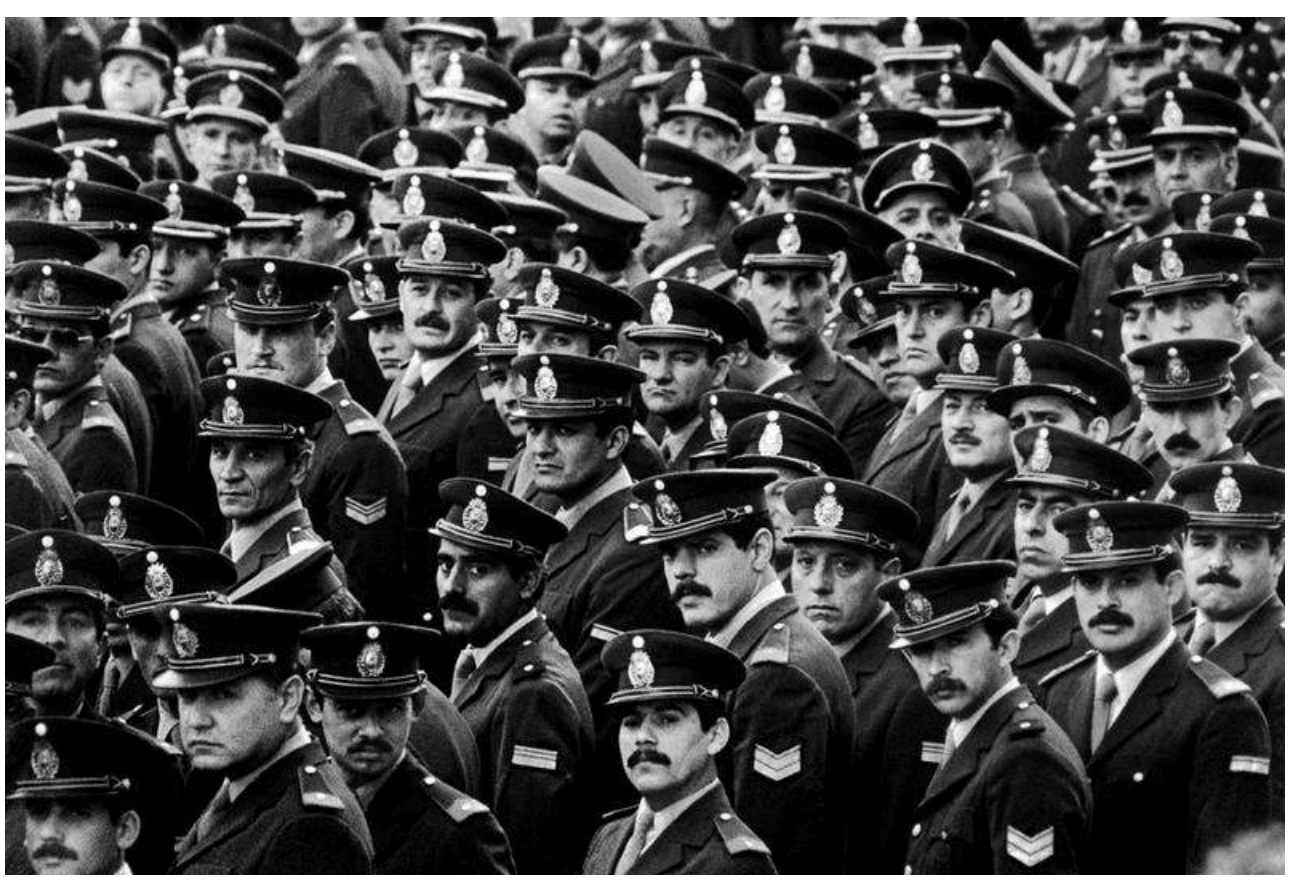

Autor Eduardo Longoni

$7 \quad$ En esta oportunidad los organizadores dispusieron de cuadernos para que el público se expresara: "Debe ser visita obligada de todos los alumnos secundarios del país"; "Gracias por mostrarnos la realidad"; "Es obligación verla"; "Gracias a los milicos tenemos exposiciones como estas. Dios quiera que no haya otra"; “¡Cuánto dolor !"; "Ustedes nos hacen ver las cosas que tan solo miramos"; "Ni olvido ni perdón"; "Me conmovió. No lo olvidaré. Tampoco mis hijos, mis nietos. Algunas me ayudarán a observar el período próximo con más cautela”; “Tengo 70 años. Creí que mi capacidad de asombro estaba colmada pero ¡no! Basta de esto, que nunca nos olvidaremos. ¡Viva la democracia !" ; "Estas fotos están muy bien tomadas, deberían salir en los diarios" (9 años) ${ }^{3}$. La última frase, escrita por un niño, apuntaba al centro mismo de la cuestión de la complicidad mediática con la dictadura. Estas fotos no habían sido publicadas en la prensa masiva ${ }^{4}$.

\section{Los fotoperiodistas en democracia}

8 Los primeros años luego de recuperada la democracia se caracterizaron en Argentina por una reorganización de la esfera pública ${ }^{5}$ (Habermas, 1994). El entusiasmo preelectoral había invadido todos los ámbitos sociales. La necesidad de ver y discutir sobre distintos aspectos políticos y sociales influyó en la diversificación de espacios y temáticas en los que los reporteros gráficos se desempeñaban, en las imágenes que obtenían y en la organización que a sí mismos se daban. La democracia tan anhelada y la celebración por la recuperación del espacio público en aquellos primeros años obturaron en un primero momento la posibilidad de ver las líneas de continuidad entre el gobierno militar y la naciente democracia. A grandes rasgos, hubo en la sociedad en general una idealización de la democracia como contracara de la dictadura. Aún no 
habían llegado ni la desilusión ni el desencanto. En ese contexto algunos reporteros gráficos tomaron fotos que iniciaron un largo recorrido contra el olvido.

Los fotógrafos emergieron fortalecidos como colectivo al finalizar la dictadura. Habían realizado las tres primeras muestras de Periodismo Gráfico en el país (1981, 1982 y 1983), en las que habían expuesto fotos de una altísima repercusión entonces y que siguen siendo íconos de ese pasado hasta hoy: imágenes de las grandes manifestaciones de 1982 y 1983, escenas de represión en las calles, fotos de las Madres de Plaza de Mayo, de la recuperación de la vida política, de la campaña electoral. Algunos fotógrafos y algunas fotografías en particular señalaban el peligro que aún representaba ese pasado autoritario.

1984 fue un año clave en la organización de los fotógrafos. El Grupo de Reporteros Gráficos que había organizado las tres primeras muestras de periodismo gráfico por fuera de la asociación que los agrupaba asumió la conducción de la ARGRA (Asociación de Reporteros Gráficos de la República Argentina). Relanzaron la revista Reportero Gráfico bajo la dirección de Guillermo Loiácono y comenzaron a activar diversas reivindicaciones gremiales y laborales.

Figura 4: Tapa de la revista Reportero Gráfico, editada por la Asociación de Reporteros Gráficos de la República Argentina (ARGRA). Noviembre 1984

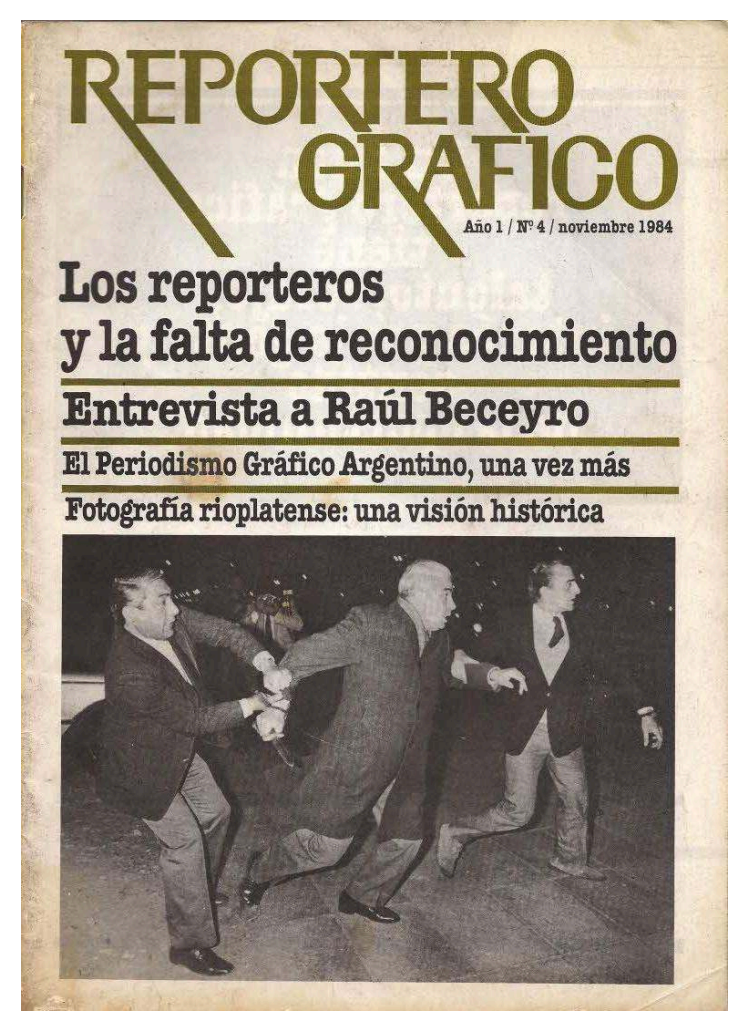

11 A fines de 1983 y durante todo 1984, se sucedieron una vorágine de acontecimientos en el país. Alfonsín asumió con una cuota de poder reducida mientras los sectores golpistas se mantenían al acecho. De hecho, en los primeros meses de gobierno hubo numerosos intentos de erosionar al gobierno electo con campañas en distintos diarios y revistas como Somos, Ámbito Financiero, La Prensa, La Nueva Provincia, Cabildo (Ferrari, 2013). 
12 El repudio popular a la dictadura había ido in crescendo a medida que se revelaba el horror de los crímenes. Este develamiento (realizado en muchos casos con un tratamiento de show mediático por la misma prensa que había apoyado al régimen) trajo consigo un masivo sentimiento de indignación y la condena a la represión ilegal se extendió más allá de diferencias ideológicas y políticas.

13 Las muestras de periodismo gráfico de 1984 y de 1985 reflejaron la ebullición social de esos años. Los fotógrafos, ya más lejos de la represión directa de la dictadura, se permitieron fotografiar nuevos temas y ensayar nuevos recursos. Se ven más nítidamente en estas muestras ensayos documentales, fotos de grandes acontecimientos periodísticos e imágenes metafóricas.

14 Cada muestra en su síntesis nos permite ver como en un caleidoscopio los principales personajes y acontecimientos políticos de esos años. En ese sentido muestran un clima de época que atravesado por múltiples miradas permiten descubrir "el cristal del acontecer total”. Como señaló Walter Benjamin: “... retomar para la historia el principio del montaje. Esto es, levantar las grandes construcciones con los elementos constructivos más pequeños, elaborados con precisión y nitidez. Descubrir entonces en el análisis del pequeño momento singular el cristal del acontecer total" (Benjamin, 2005: 463)

Las muestras pueden ser analizadas como una especie de montaje, imágenes superpuestas una al lado de la otra que forman en conjunto una unidad aun en su diversidad. El montaje de las imágenes en estas muestras funda su eficacia en la posibilidad que brinda para activar memorias latentes. Las fotografías de esos primeros años de la postdictadura son superficies de inscripción privilegiadas para ver cómo funcionaron complejos procesos de construcción de memoria.

Los reporteros gráficos, al montar sus imágenes en una muestra que se proponía sintetizar los acontecimientos más relevantes de ese año, conformaban un nuevo discurso. A la selección de imágenes que realizaba cada fotógrafo se le sumaba la forma en que se organizaba el recorrido de la exposición. Vistas en conjunto, las fotos convocaban a nuevos sentidos por asociaciones múltiples que podía realizar cada visitante. A su vez, como señala Benjamin, montar una exposición es un acto político, es tomar una postura. Tanto en la muestra de 1984 como en la de 1985 se observan fotos de sufrimiento, irónicas, de humor, fotos de esperanza, de búsqueda, fotos transgresoras, de denuncia, fotos de los principales personajes políticos de cada año, fotos de violencia, de acontecimientos periodísticos como incendios, accidentes de tránsito, fotos deportivas. Fotos que muestran la pobreza, la desesperación. Fotos documentales : los indios del noreste argentino, un ensayo sobre la salud mental, una casa de estudiantes, el trabajo en las minas, obreros del puerto, distintos oficios, los familiares de presos durante un motín. Siguen muy presentes las fotos del movimiento de derechos humanos y las fotos críticas a la Iglesia. Hay fotos internacionales, especialmente de Nicaragua, Chile y Bolivia. Fotos de manifestaciones y de partos (ambas estrechamente relacionadas entre sí en esos años). También imágenes de la reactivación política y de personajes que, más tarde sabríamos, tuvieron un rol clave durante la dictadura militar.

17 Las muestras les posibilitaban a los fotógrafos realizar una edición propia, lo que fue un salto importante en la valoración de su autonomía. Sacadas de su espacio habitual, la prensa, las imágenes se desplazaban a otro nivel de legibilidad. Mientras la fotografía en la prensa es un género subordinado a otros discursos y a las decisiones de edición y 
diseño que toman otros (en la prensa, esas mismas fotografías debían formar parte del juego intertextual que se generaba a partir de la ubicación y la editorialización que se hacían en ese medio), en las muestras, los propios fotógrafos decidían cómo colgarlas, en qué orden, con qué epígrafes. Las fotos, aisladas de títulos, copetes o epígrafes puestos por otros, generaban un discurso autónomo creado por los propios fotógrafos.

Las muestras nos proveen una selección de las fotografías de prensa que los fotoperiodistas más importantes de esos años decidieron exponer públicamente. Hay en ellas fotos que trascendieron el momento de esa presentación y se transformaron en los íconos que se suelen utilizar para relatar lo que sucedió aquellos años. Son imágenes que sostienen los vínculos entre memoria y fotografía. Como señala Hugo Vezzetti, el pasado requiere, para convertirse en una experiencia operante y transmisible, de imágenes y relatos, tanto como de interpretaciones racionales y conceptualizaciones (Vezzetti, 1996: 5). Para los años 1984 y 1985, hay especialmente dos fotografías que funcionaron en ese sentido y fueron de las más significativas en cada una de las muestras realizadas esos años.

Figura 5: Tapa del catálogo de la Cuarta Muestra de Periodismo Gráfico Argentino. Noviembre 1984.

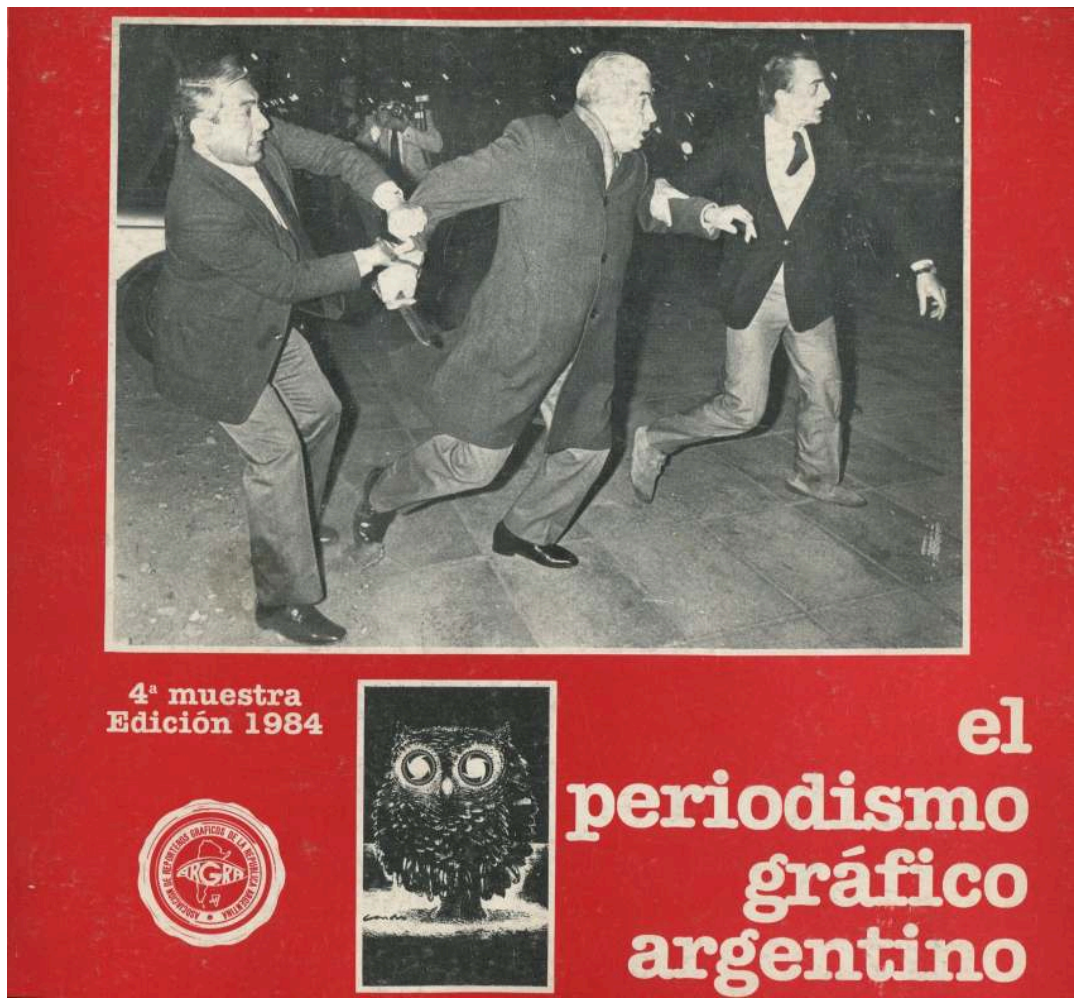


Figura 6: Tapa del catálogo de la Quinta Muestra de Periodismo Gráfico Argentino. Noviembre 1985

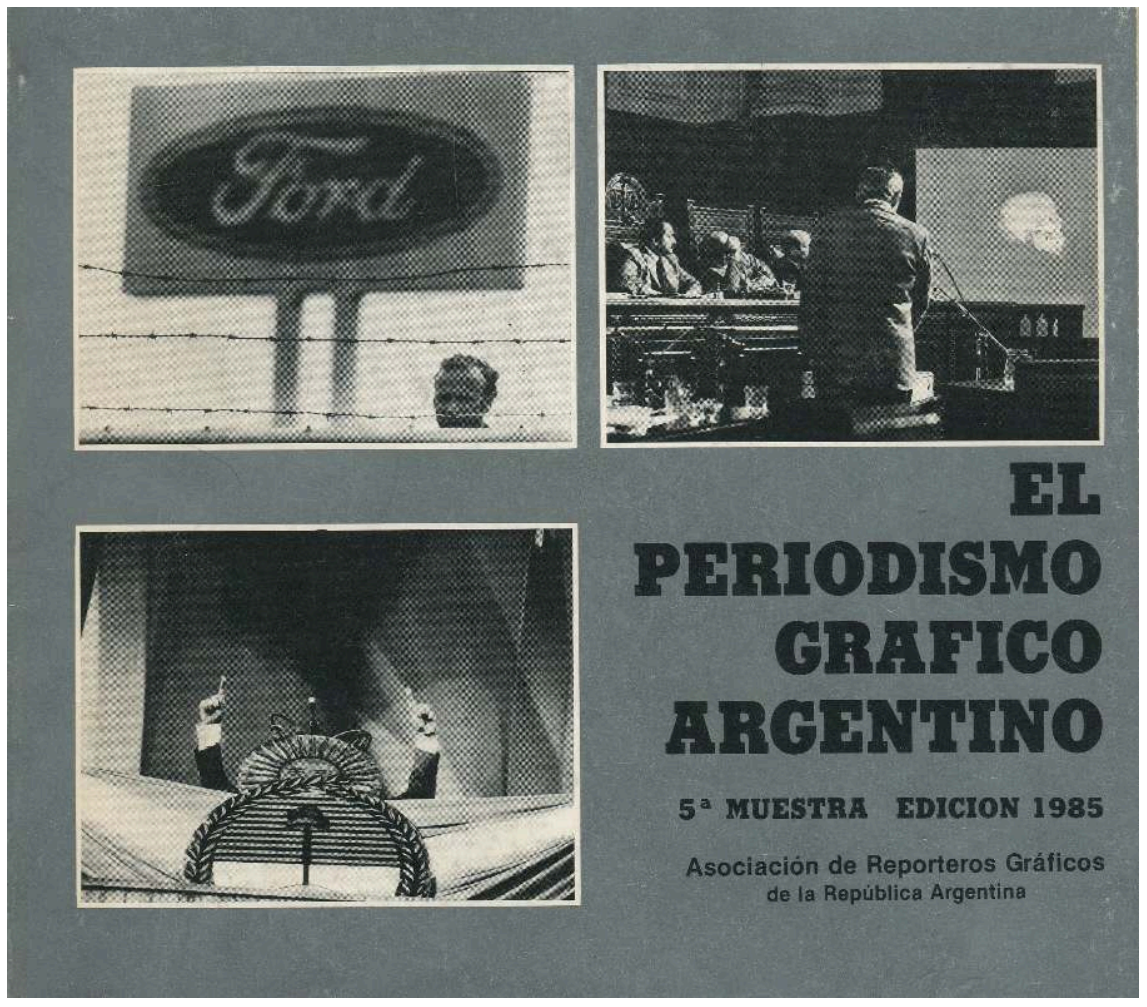

\section{La punta del iceberg}

En la noche del 21 de agosto de 1984 el fotógrafo Enrique Rosito tomó una foto que muestra la siguiente escena: Luciano Benjamín Menéndez ${ }^{6}$, con un cuchillo en la mano, se abalanza sobre unos manifestantes (que quedan fuera de cuadro) mientras dos de sus custodios intentan contenerlo. Al fondo se ve un fotógrafo registrando la escena desde otro ángulo. 
Figura 7: El represor L. B. Menéndez se abalanza con un cuchillo en la mano contra unos manifestantes, Buenos Aires, 21 de agosto 1984

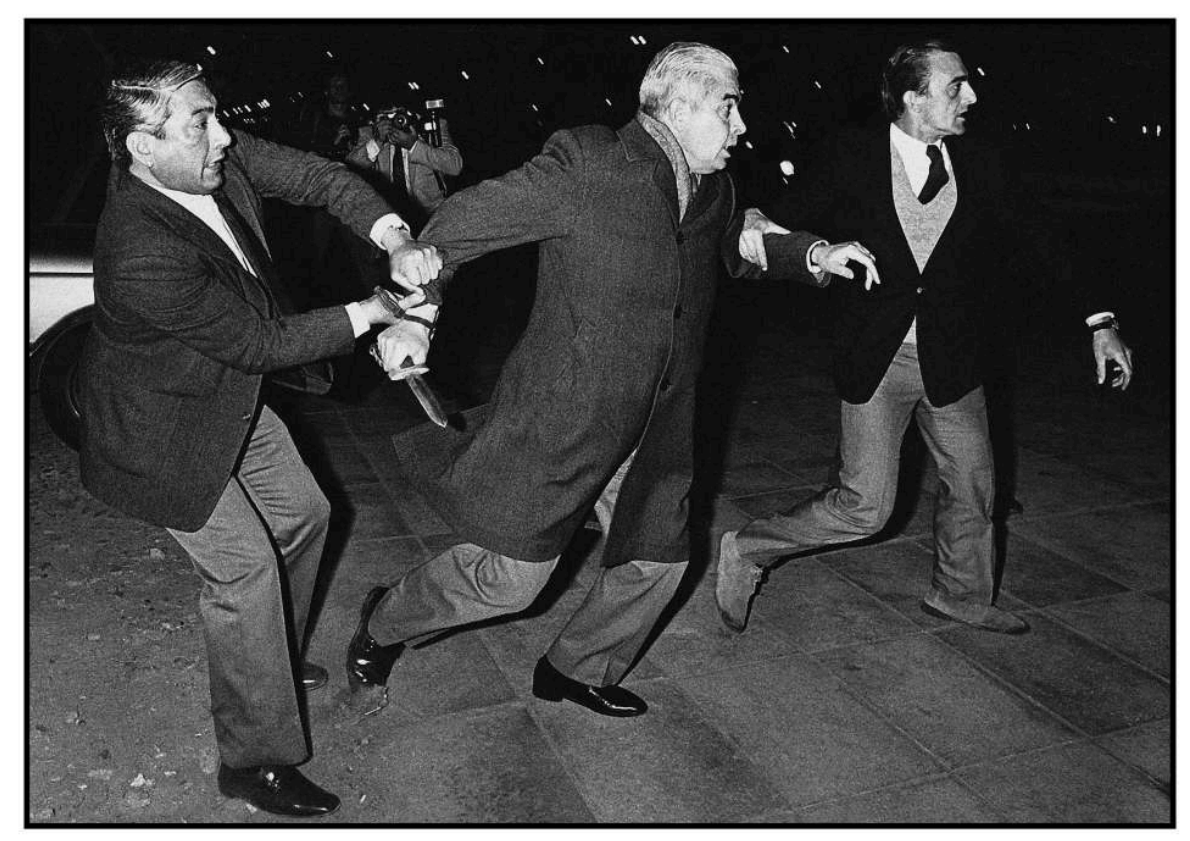

Fotógrafo Enrique Rosito

\section{humanidad que había cometido y los conductores del programa de televisión Tiempo Nuevo, Bernardo Neustadt y Mariano Grondona, le otorgaban la legitimidad necesaria como para invitarlo a un debate televisivo sobre el referéndum previo al tratado de límites con Chile por el canal de Beagle.}

\section{Enrique Rosito señala acerca del momento en el que tomó esta fotografía:}

Por esa época trabajaba en la agencia DYN. [...] Al llegar al canal, vi que afuera estaban las Madres de Plaza de Mayo y otros militantes que le gritaban a Menéndez asesino y cobarde. Él se retiraba en un Ford Falcon, sentado en el asiento derecho de atrás. Delante del auto salía un colectivo de la policía que había ido a custodiarlo. Yo pensé que el colectivo nos iba a tapar entonces salté para el otro lado. Ahí fue que Menéndez bajó del auto y encaró hacia los jóvenes. Estaba oscuro, tuve que utilizar el flash. En ese momento creí que tenía un revólver en la mano. Dos tipos, un custodio y otro que resultó ser su hijo lo agarraron para que no pueda avanzar. Era de noche, estaba todo oscuro y en esa época no había autofocus. Había que enfocar con la mano. [...] Hice solo tres fotos, hago la tercera y se me corta el rollo. A todo esto baja la infantería, empieza a repartir palos a los manifestantes que había, los cagaron a palos. Yo estaba ahí con la cámara pero no podía hacer nada más. Entonces decido irme a revelar, para ver qué había podido sacar y uno de los manifestantes me grita "sacá, cagón, no te vayas" iy yo no les podía explicar! Me fui a la agencia, eran las 12 de la noche, revelé, mandamos a los diarios y me quedé esperando a ver qué salía. A la madrugada la foto salió en la tapa de Clarín" (Entrevista de la autora a Rosito, 2011).

El fotógrafo cuenta la forma en que obtuvo la imagen. Menciona detalles que nos hablan de la forma en que ejercía su trabajo : la observación, los reflejos, la ubicación en el espacio, la espera, las decisiones en función de la luz, las determinaciones técnicas que incidieron en sus decisiones y en sus resultados, la cuota del azar. El testimonio 
muestra también la necesidad de los manifestantes de que el momento sea registrado, de que se vuelva visible. Su declaración nos permite observar cómo el fotógrafo operó con las limitaciones técnicas, de espacio y de tiempo. También nos da indicios del trabajo posterior del reportero. En la época de la fotografía analógica no sabía lo que había obtenido hasta el momento del revelado y una vez que culminaba la obtención de las imágenes, debía trasladarse hasta un laboratorio, revelarlas, seleccionar, editar y enviar a los medios.

El único diario que tuvo los reflejos rápidos y pudo cambiar su tapa a esa hora de cierre fue Clarín, pero lo hizo con un epígrafe en el que se señalaba que el hostilizado por los manifestantes había sido Menéndez y que frente a ese hecho el militar había reaccionado. Bajo el título de "Menéndez : grave incidente", el epígrafe señalaba : "A la salida de Canal 13, donde había concurrido para participar de un programa periodístico, el general (RE) Luciano Benjamín Menéndez fue hostilizado por un grupo de manifestantes. El militar reaccionó extrayendo un arma blanca. Dos de sus acompañantes lo contuvieron" (Diario Clarín, Tapa, 22 de agosto de 1984)

El impacto y la trascendencia que tuvo esta foto nos habla del rol que ejerció una parte, al menos, del fotoperiodismo en Argentina en esos años. En la imagen se veía con claridad a Menéndez con un cuchillo en la mano, que después se supo era un cuchillo de paracaidistas de unos $35 \mathrm{~cm}$ de largo. Menéndez había intentado embestir contra los manifestantes, quienes además fueron reprimidos por la policía. Cuatro de ellos quedaron detenidos ${ }^{7}$.

Frente a la contundencia de la imagen, la repercusión nacional e internacional fue inmediata. La foto no permitía lecturas ambiguas. Los días siguientes salió publicada en la primera plana de los principales diarios nacionales e internacionales : difundida por DYN y UPI salió en el New York Times, Daily News, Herald Tribune, Los Angeles Times, Chicago Tribune, Miami Herald, El País y en múltiples diarios y revistas de América Latina y Europa ${ }^{8}$. El diario de la izquierda francesa Libération la publicó con el título: "Al que me grita asesino lo mato". En Argentina todos los diarios de tirada nacional sacaron la información en tapa durante toda la semana. El sábado 25 de agosto los medios anunciaban que se le dictaría prisión preventiva rigurosa a Menéndez (Clarín, La Voz, Tiempo Argentino y La Nación, 25 de agosto de 1984). 
Figura 8: Primera plana del diario Clarín, Buenos Aires, 22 de agosto de 1984.

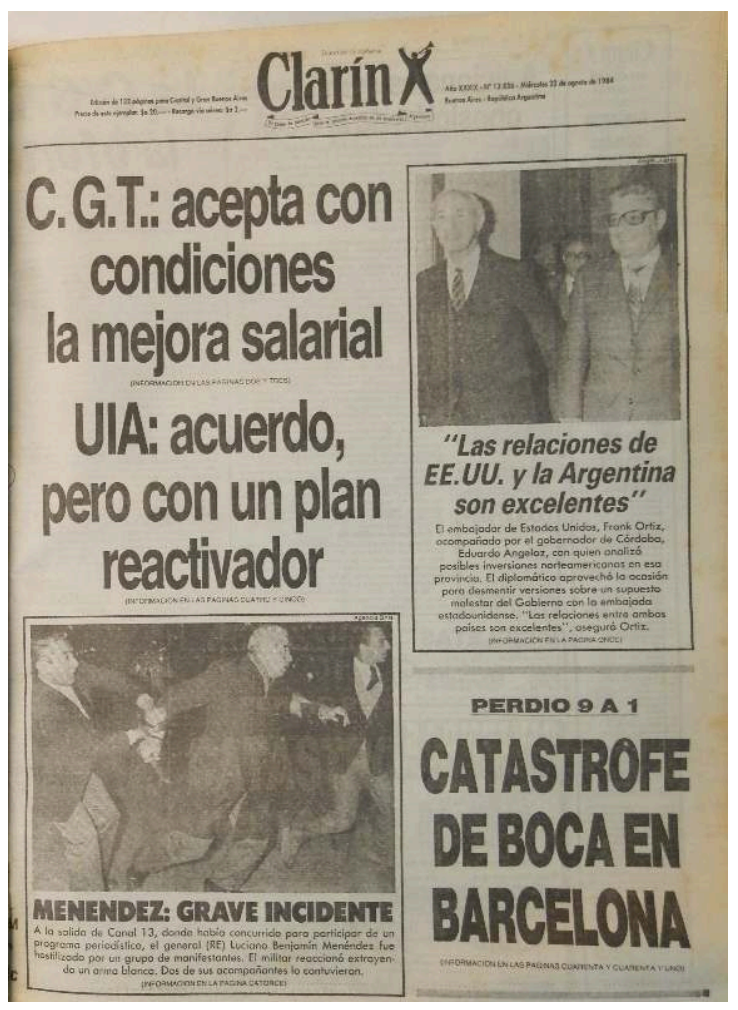

La foto que dejaba al desnudo la fragilidad de la democracia argentina desató un papelón internacional y cayó como un rayo sobre el gobierno alfonsinista. Un militar probadamente asesino estaba en libertad y era capaz de empuñar un cuchillo en plena calle contra jóvenes y madres.

La visibilidad que le dio la existencia de la fotografía al hecho fue crucial para todo lo que se desencadenó después ${ }^{9}$. La foto también habla de las diferencias de los distintos actores sociales y de las posibilidades en democracia de impedir el accionar de impunidad de los represores. Si bien estaba libre y había sido invitado a un programa de TV, la presencia de los manifestantes y de un grupo de madres de desaparecidos habla de otro momento histórico en el país. La impunidad total ya no era posible.

La acción de un puñado de jóvenes militantes de izquierda y de un grupo de Madres de Plaza de Mayo logró que su intervención, que no había sido masiva en los hechos, obtuviese una trascendencia mundial gracias a la contundencia de la imagen y a la eficacia de la difusión periodística. La labor de los fotógrafos que estaban allí permitió dar visibilidad nacional e internacional al hecho y amplificar el reclamo ${ }^{10}$. Haber sido el jefe de uno de los más grandes campos de concentración de la dictadura no había bastado para que Menéndez estuviese preso. La difusión de la fotografía lo logra. El miércoles 29 de agosto quedó detenido con prisión preventiva por "excesos represivos". 


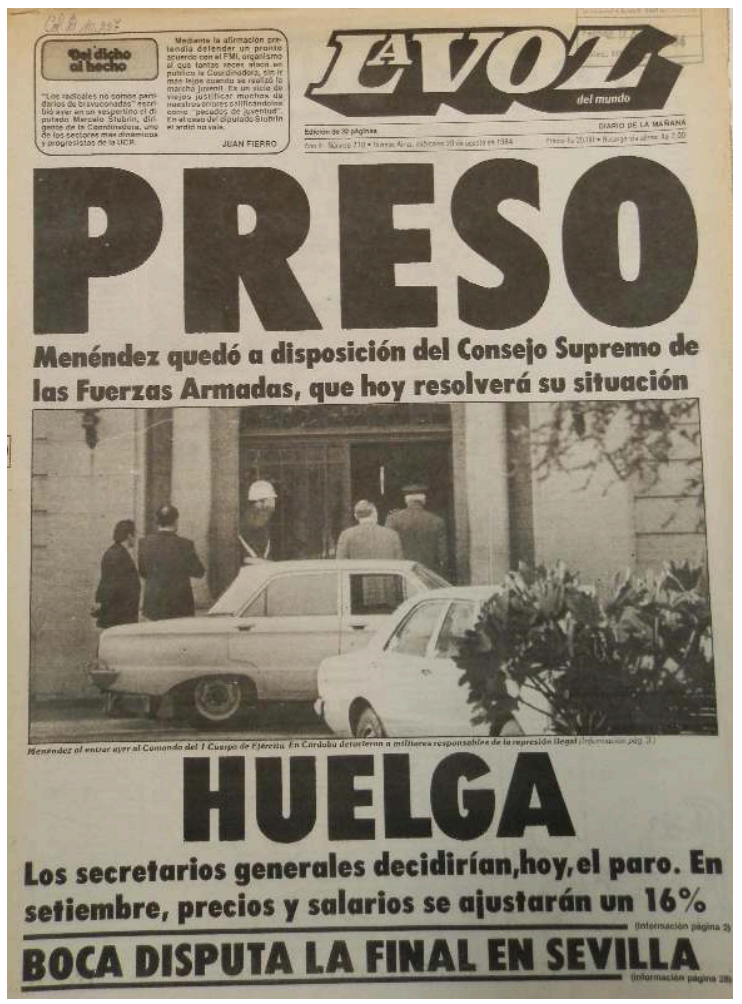

La foto ganó el premio Rey de España ${ }^{11}$ del año siguiente. Esa escena resumía la violencia, la omnipotencia y la impunidad de los hombres que habían detentado el poder en Argentina durante los años del terrorismo de Estado. Al mismo tiempo, denunciaba al gobierno electo que lo dejaba en libertad y a los periodistas que lo invitaban como panelista especial a participar de un programa de televisión. La foto mostraba en múltiples sentidos la punta de un iceberg.

\section{La fotografía como agujero y aguijón}

El terrorismo de Estado para su aplicación había implementado en Argentina una rigurosa política de desinformación, censura y manipulación mediática para lo cual utilizó poderosos mecanismos de inteligencia bajo el control del Estado. Esto le permitió instalar una efectiva política de ocultamiento de sus crímenes ${ }^{12}$. La sociedad en su conjunto había podido ver imágenes de la represión pública ejercida por las fuerzas armadas recién a partir de finales de 1981. En 1984 no se conocían fotografías salidas del interior de los centros clandestinos de detención ${ }^{13}$. Ver a Menéndez blandiendo un cuchillo en plena calle frente a los manifestantes significó entonces una revelación. Si esto hacía a la vista pública, en democracia, a la salida de un canal de televisión y con cámaras enfocándolo, ¿qué habría hecho este represor en los oscuros subsuelos de los campos clandestinos durante la dictadura?

Frente a la difusión de esta imagen, el presidente electo Raúl Alfonsín quedó entre dos fuegos. Por un lado, el escándalo internacional amplificado por la publicación de la fotografía en los principales diarios del mundo. Por el otro, la presión militar que pugnaba por perpetuar la impunidad. Para las organizaciones de derechos humanos la fotografía resultó un apoyo inesperado y de efectividad contundente. Legitimaba sus 
denuncias y lograba que se concretase un reclamo, la cárcel para el genocida, por el que se habían movilizado miles de personas, en incontables ocasiones, sin haberlo conseguido. A una semana de la publicación de la fotografía, Menéndez quedó detenido a disposición del Consejo Supremo de las Fuerzas Armadas. Esa imagen de un asesino libre que amenazaba impunemente a manifestantes y periodistas era a su vez la contracara de la imagen que el presidente Alfonsín había transmitido sobre sí mismo: un estadista preocupado por las formas democráticas y por hacer cumplir el estado de derecho. Esta foto, con su factor de prueba, su rol de denuncia y su fuerza simbólica, colaboró para "descompaginar" el proceso de consolidación de la impunidad que se intentaba naturalizar.

Había en esta foto algo intrínseco que la volvía poderosa. Ningún medio se quería privar de una imagen con esta capacidad de impacto. La prensa, aún la que había sido cómplice del régimen, amplificó la denuncia y distintos actores sociales sumaron su voz pidiendo esclarecer e investigar lo sucedido. De esta forma, el fotógrafo resultó ser un eslabón clave en una cadena de hechos que a su vez derivó en otras reacciones políticas y sociales que se sucedieron luego de su publicación.

35 En este caso se dio la excepcionalidad de que fue la existencia misma de la fotografía lo que modificó el suceder del acontecimiento. Si la imagen no se hubiese producido, Menéndez habría estado menos tiempo preso aún del que estuvo. Compone en ese sentido lo que Didí-Huberman denomina un "acontecimiento visual" (Didí-Huberman, $2004: 65)$.

36 Al mismo tiempo esta foto puede entenderse en toda su complejidad si es leída y analizada como parte y producto de los procesos históricos, sociales y tecnológicos que la hicieron posible y, al mismo tiempo, que le dieron (y dan) sentido. Roland Barthes señalaba que las fotografías tienen una "fuerza constatativa" ${ }^{14}$ que atañe más al tiempo que al objeto. Según el semiólogo francés, este "poder de autentificación" es el poder de la fotografía. John Tagg, retomando la categoría de Barthes, agrega que esa fuerza constatativa "es un complejo resultado histórico, y es ejercido por las fotografías solamente dentro de ciertas prácticas institucionales y relaciones históricas concretas..." (Tagg, 2005: 11).

Esta foto tiene sin duda esta fuerza constatativa, pero no por el carácter indicial de la fotografía que obviamente también porta, sino por una necesidad social, sostenida y defendida de memoria y justicia, encarnada en actores concretos y por el uso que le dieron a lo largo del tiempo múltiples actores sociales, instituciones y medios. En este caso la fotografía actuó como catalizadora y potenciadora de otros reclamos sociales. Frente al manto de olvido y perdón que se intentaba instalar, la foto irrumpió provocando un agujero que daba fuerza al discurso por la memoria, la verdad y la justicia. De esta manera, ayudó a legitimar los reclamos de los organismos de derechos humanos. Al mismo tiempo fue un aguijón para aquellos sectores que pretendían "dejar el pasado atrás".

Mientras se intentaba instalar la lógica del peligro de juzgar a los represores en pos de la defensa de la democracia, la imagen mostró (especialmente para la amplia opinión pública) que el peligro era dejar libre a un represor como Menéndez. La impunidad no podía ser una opción, era en todo caso una locura. Por otro lado, la repercusión de esta foto en medios internacionales anclaba en un territorio conocido y se conectaba con las 
denuncias realizadas durante años por distintas organizaciones de derechos humanos y grupos de exiliados en el exterior.

Más allá de su publicación momentánea, la foto comenzó un recorrido autónomo de la agencia que le dio origen y adquirió nuevos significados. Su publicación ayudó a potenciar la denuncia, trascendió lo local y adquirió una visibilidad social imprescindible para impulsar los juicios por delitos de lesa humanidad en el país. Como señaló Walter Benjamin, fue una imagen que nos permitió apoderarnos de un recuerdo, tal como surgió en el instante del peligro.

\section{Una foto ética frente al "show del horror"}

En los primeros meses de 1984, el llamado "destape" mediático con el cual la prensa se liberaba de la censura y de lo prohibido durante la dictadura (sexo, "malas palabras", cuerpos desnudos, etcétera) convivió con noticias acerca de la desaparición de personas y la irrupción en la escena mediática de los hallazgos de cadáveres Nomen Nescio (NN) en enterramientos masivos. Muchos medios que habían sido cómplices y parte central del andamiaje cultural de la dictadura se "adaptaron" a los tiempos democráticos a través de la publicación de estas noticias. Las exhumaciones de tumbas anónimas, realizadas en el marco de las primeras investigaciones sobre el destino de los desaparecidos en cementerios en todo el país, convivían con la desnudez, las chicas de tapa y los temas "audaces". Esta puesta en escena mediática fue denominada por algunos actores como el "show del horror" (Feld, 2014) ${ }^{15}$.

Paralelamente a este "destape", durante el año 1985 se realizó el Juicio a las Juntas Militares que habían gobernado el país durante la dictadura, por su responsabilidad en delitos de lesa humanidad. Frente a la profusa difusión de las imágenes sensacionalistas que se habían podido ver sobre todo en 1984, la Cámara Federal que juzgaba a los excomandantes había decidido, según la Acordada $14{ }^{16}$, que se prohibiera el ingreso de camarógrafos y fotógrafos a las salas donde se desarrollaría el Juicio. Según señala Claudia Feld, "la Acordada prohibió 'el ingreso de periodistas con cámaras fotográficas, cinematográficas o de vídeo-, con micrófonos o con grabadores', y dispuso la presencia de 'cuatro fotógrafos oficiales que distribuirán las imágenes que obtengan a los distintos medios y agencias periodísticas'. Estas fotografías se tomaban en los momentos iniciales y finales de cada audiencia, evitando así perturbar los testimonios" (Feld, $2002: 21)^{17}$.

Todos los medios de prensa repartirían luego esas imágenes. Eduardo Longoni y Daniel Muzio fueron dos de los fotógrafos acreditados. Daniel Muzio cuenta:

En principio la cobertura fue complicada porque la Cámara Federal no quería imágenes del juicio. Después de varios días de negociación se logró que ingresara un pool. Un fotógrafo por diarios, un fotógrafo por agencias y un fotógrafo por las revistas. A mí me tocó formar parte del pool como fotógrafo de agencias. Se iba a distribuir la misma imagen para todos los medios. $Y$ las jornadas de trabajo eran realmente largas porque el juicio comenzaba a las tres de la tarde y no se sabía a qué hora terminaba (Muzio, 2010).

El 30 de marzo de 1985, en ese contexto de trabajo, Muzio captó la imagen que se transformó en el símbolo del Juicio. La foto fue obtenida en una audiencia en la que el científico Clyde C. Snow, miembro de la delegación de científicos forenses y genetistas enviada por el "Programa de Derechos Humanos y Ciencias" de la Asociación 
Americana para el Avance de las Ciencias, explicaba a los jueces las características de los impactos de bala en cadáveres $N N$ hallados en fosas comunes.

Figura 1 : Una escena del Juicio a las Juntas Militares, Buenos Aires, 30 de marzo de 1985.

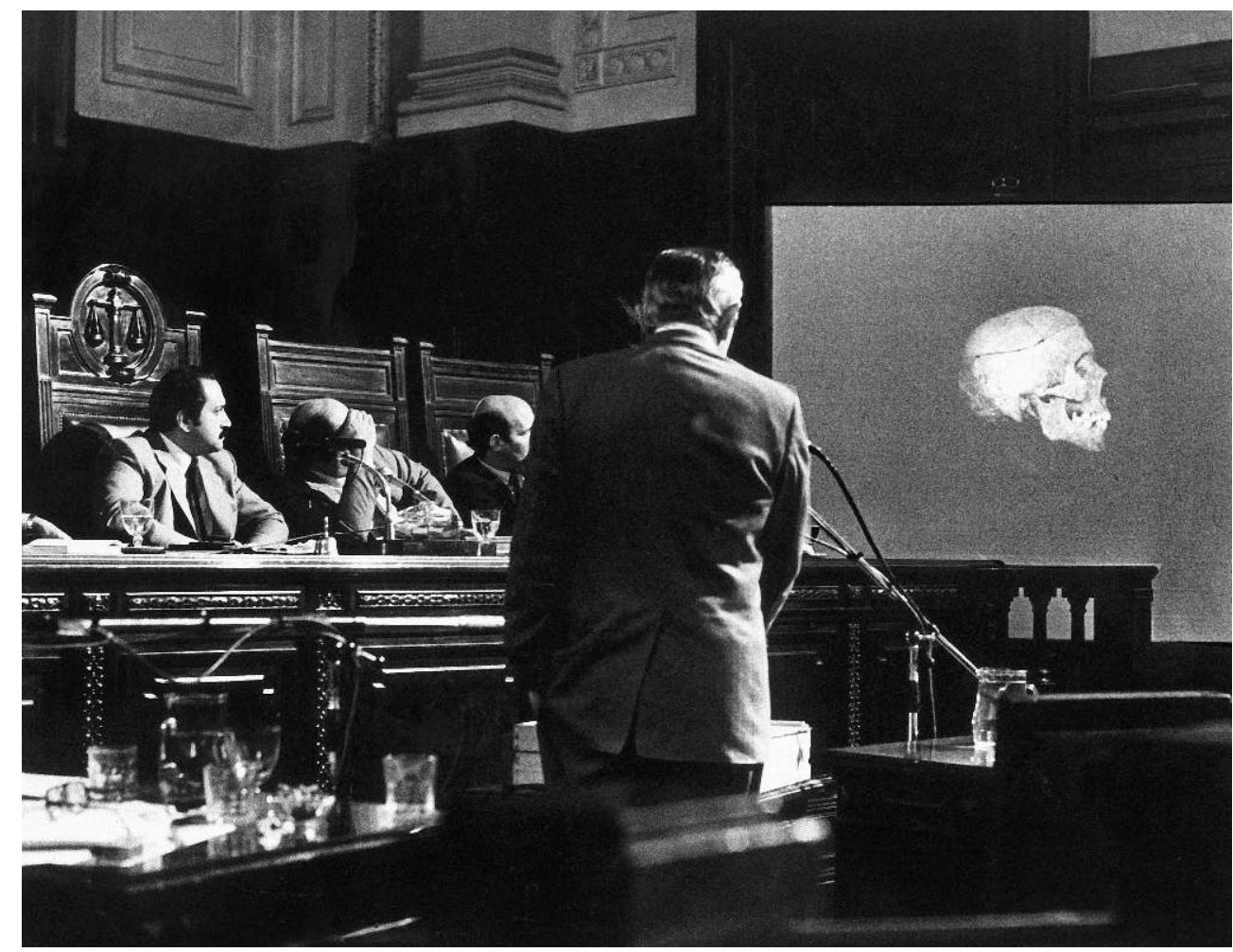

Autor : Daniel Muzio.

Esta información permitía determinar una de las formas en que algunas víctimas habían sido asesinadas. El especialista había sido contactado por la Comisión Nacional sobre la Desaparición de las Personas (CONADEP), formada a fines de 1983 por el Poder Ejecutivo Nacional. Máximo Eseverri señala al respecto de esta fotografía:

La situación es a la vez solemne y didáctica: la imagen del cráneo es prueba de un crimen y al mismo tiempo retrato de una víctima. Así como en uno de los extremos de la fotografía la balanza tallada en el sillón de Arslanián simboliza la justicia, en el otro, el cráneo proyectado sobre la pantalla representa la muerte. [...] El denso carácter simbólico de la calavera es a su vez contrapunteado por el carácter indicial de ese mismo objeto representado : en su recuperación, se recobra también una materialidad que parecía perdida inexorablemente, la del cuerpo de un hombre sometido violentamente a una desaparición forzada, una muerte anónima, privado de una tumba digna [y agrega] la toma de Muzio ofrece un marco de referencia y de reflexión a otra imagen, que evoca, a su vez, en clave científica, los restos óseos de una víctima (Eseverri, 2013).

El fotógrafo a su vez relata:

Cuando tomé esta foto, no tomé conciencia de lo que pasaba. La jornada había comenzado a las 15 y eran cerca de las 5 de la mañana cuando el científico Snow les explicaba a los jueces cómo podían identificar cadáveres [...]. A mí me parece que la imagen es muy fuerte, estamos hablando de un juicio donde se juzgó desapariciones, torturas. El cráneo en este ambiente de penumbra, con los jueces, 
da una sensación como que resuelve un poco la historia del juicio. Fueron muchos meses de jornadas muy largas y realmente no había mucho para fotografiar, los espacios eran muy reducidos, los testigos se podían fotografiar solo cuando entraban o cuando salían, lo mismo los excomandantes. Entonces esto cambió un poco, porque cambió la imagen que se venía viendo del juicio. El día de la sentencia fue un día bastante raro, porque si bien uno estaba trabajando tratando de documentar una historia, lo que me pasó personalmente fue que me embargó una emoción increíble cuando el juez dictó la sentencia. El público estalló en festejos y realmente no podías no conmoverte después de haber estado ahí tantos meses escuchando testimonios, muchos terribles, terribles, realmente terribles. Fue increíble haber estado en ese lugar.

[...] El público se levantó de las butacas y comenzó a aplaudir. Yo perdí el control de lo que estaba haciendo, si yo estaba documentando o era parte del público, fue muy fuerte. Realmente muy fuerte (Muzio, 2010). dicho juicio ${ }^{18}$. Junto con otras fotografías de los reporteros gráficos que pudieron presenciar y fotografiar entonces el Juicio a las Juntas, nos señala un recorte de lo que valió la pena subrayar. Pero su foto es también una toma de posición tanto en el plano de la formas como en el de los contenidos. La imagen del Juicio permitió mostrar los sucesos traumáticos que se relataron allí sin recurrir a la espectacularización del horror. Esta foto, junto con otras tomadas por múltiples reporteros gráficos, circularon bajo el telón de fondo de las imágenes, sensacionalistas e impactantes de cierta prensa masiva demostrando que existía una manera ética de narrar lo sucedido bajo el terrorismo de Estado. Hay tanto en esta imagen como en la foto de E. Rosito una elaboración estética que permitió, tanto al fotógrafo como a quien ahora la observa, tomar distancia y al mismo tiempo involucrarse en el hecho. el espacio social que es por definición el terreno en disputa en el cual se desarrollan los hechos políticos. A diferencia de la distancia que permite la escritura, la fotografía exige la presencia física del realizador en el escenario de los acontecimientos. Los fotógrafos transformaron una experiencia vivida en una puesta en escena. "Estuvieron 
allí" en donde sucedían los hechos y fueron atravesados por esos sucesos. Sus fotos son aportes concretos al proceso de construcción de la democracia en Argentina.

Son imágenes que se transformaron en "acontecimientos visuales" al mismo tiempo que en "constatación" de los hechos. Estos fotógrafos se distanciaron para mostrar y frente al "show del horror" adoptaron un punto de vista ético. No había casualidad en sus fotos, ni solo un 'momento oportuno' sino fundamentalmente una toma de posición.

\section{BIBLIOGRAFÍA}

BARTHES Roland, La cámara lúcida. Nota sobre la fotografía. Buenos Aires, Paidós, 2008 [1980].

BENJAMIN Walter, Libro de los Pasajes (1927-1940), Madrid, Akal, 2005.

BENJAMIN Walter, Sobre el concepto de historia, Obras, libro 1, volumen 2, Madrid, 2008.

CEROLINI Pablo y REYNOSO Alejandro (comps.), En negro y blanco. Fotografías del Cordobazo al Juicio a las Juntas, Bs. As., ARGRA, 2006.

DIDÍ-HUBERMAN Georges, Cuando las imágenes toman posición, Antonio Machado Libros, Madrid. Trad. Inés Bértolo, 2008.

DIDI-HUBERMAN Georges, Imágenes pese a todo. Memoria visual del Holocausto. Barcelona, Paidós, 2004.

ESEVERRI Máximo, "Estética y política en dos imágenes de antropología forense", in Instantáneas de la memoria. Fotografía y dictadura en Argentina y América Latina, Libraria, Buenos Aires, 2013.

FELD Claudia, Del estrado a la pantalla: las imágenes del juicio a los ex comandantes en Argentina. Buenos Aires, Siglo XXI, 2002.

FELD Claudia, "La representación de los desaparecidos en la prensa de la transición: el 'show del horror"', in Los desaparecidos en la Argentina. Memorias, representaciones e ideas (1983-2008), Crenzel, E. (coord.), Buenos Aires, Biblos, 2010.

FELD Claudia, “¿Hacer visible la desaparición?: las fotografías de detenidos-desaparecidos de la ESMA en el testimonio de Víctor Basterra", in Clepsidra. Revista Interdisciplinaria de Estudios sobre Memoria, № 1, marzo, 2014, p. 28-51.

FERRARI Germán, 1983. El año de la democracia, Buenos Aires, Planeta, 2013.

GAMARNIK Cora, "La fotografía de prensa antes, durante y después del golpe de Estado de 1976", in Artículos de investigación sobre fotografía, Fernández Pérez, Silvia; Gamarnik, Cora, Ediciones CMDF, Montevideo, 2011.

CUCURELLA Margarita, "La opinión pública en Habermas", revista Anàlisi. Quaderns de comunicació i cultura, Nro 26, Barcelona, 2001, p.51-70.

HABERMAS Jürgen, Historia y crítica de la opinión pública. La transformación estructural de la vida pública, Gustavo Gili, Barcelona, 1994. 
LONGONI Ana; García, Luis Ignacio, “Imágenes invisibles. Acerca de las fotos de desaparecidos”, in Instantáneas de la memoria. Fotografía y dictadura en Argentina y América Latina, Libraria, Buenos Aires, 2014.

MAZZEI Daniel, “Reflexiones sobre la transición democrática argentina”, in Revista PolHis, № 7, primer semestre, 2011.

MUZıo Daniel, “La historia íntima de la foto más famosa”, in Clarín, 09/12/10. Suplemento a 25 años del Juicio a Las Juntas, 2010.

NoVARo Marcos, Historia de la Argentina 1955-2010, Siglo Veintiuno Editores, Buenos Aires, 2010.

PORTANTIERO Juan Carlos y NUN José, Ensayos sobre la transición democrática en la Argentina. Buenos Aires, Puntosur, 1987.

VEZZETTI Hugo, "Variaciones sobre la memoria social", en Revista Punto de Vista No 56, 1996 diciembre. Buenos Aires.

\section{NOTAS}

1. Cómo nombrar esos primeros años luego del retorno a la democracia continúa siendo motivo en Argentina de debates intelectuales. Algunos los denominan como de "transición a la democracia", otros más recientemente pasaron a hablar de "postdictadura". La "transición" hace referencia a un espacio temporal acotado entre el proceso de disolución del régimen autoritario por un lado y el establecimiento de una forma de democracia : "un proceso (...), cuya primera fase es el inicio de la descomposición del régimen autoritario, la segunda la instalación de un régimen político democrático que se continúa en un tercer momento en el cual, en medio de fuertes tensiones, se procura consolidar el nuevo régimen" (Portantiero y Nun, 1987, 262). El término "postdictadura" por su parte, que adoptamos en este artículo, no hace énfasis en un recorrido lineal, sino que, por un lado, es más abarcativo en años y, por otro, remite a una redefinición del país bajo las consecuencias de la dictadura.

2. Los fotógrafos tenían previsto que la muestra se realizara, al igual que en 1982, en el local de la OEA en Buenos Aires (Organización de Estados Americanos), pero este edificio estaba en manos del Ministerio del Interior, que nunca autorizó la inauguración ni permitió que los fotógrafos pudiesen colgar la exposición.

3. “Opiniones”, en Revista Reportero Gráfico № 4, noviembre de 1984, pág. 28.

4. Los fotógrafos recuerdan también las notas en los cuadernos escritas por las propias Madres de Plaza de Mayo que les dejaban frases conmovedoras y de agradecimiento por su trabajo.

5. "Por espacio público entendemos un ámbito de nuestra vida social, en el que se puede construir algo así como opinión pública. La entrada está fundamentalmente abierta a todos los ciudadanos. En cada conversación en la que los individuos privados se reúnen como público se constituye una porción de espacio público. [...] Los ciudadanos se comportan como público, cuando se reúnen y conciertan libremente, sin presiones y con la garantía de poder manifestar y publicar libremente su opinión, sobre las oportunidades de actuar según intereses generales. En los casos de un público amplio, esta comunicación requiere medios precisos de transferencia e influencia : periódicos y revistas, radio y televisión son hoy tales medios del espacio público". Citado en Cucurella, "La opinión pública en Habermas", revista Anàlisi 26, 2001, 51-70.

6. L. B. Menéndez fue general de División, Comandante del III Cuerpo del Ejército con asiento en Córdoba, desde septiembre de 1975 hasta septiembre de 1979. Su jurisdicción abarcaba diez provincias : Jujuy, Salta, Catamarca, La Rioja, San Juan, Mendoza, San Luis, Córdoba, Santiago del Estero y Tucumán. Fue responsable de todos los campos de concentración que funcionaron en la 
zona que abarcaba el III Cuerpo, entre ellos La Perla (a $15 \mathrm{~km}$ de Córdoba, centro clandestino por donde pasaron más de 2200 personas y casi todas ellas fueron asesinadas). Supervisó y dirigió personalmente torturas y fusilamientos. No fue beneficiado por la Ley de Obediencia Debida y estaba inculpado en cerca de 800 causas. En 1984 fue detenido por primera vez a raíz de la fotografía que aquí analizamos. En 1988 fue procesado por 47 casos de homicidio, 76 de tormentos, 4 de ellos seguido de muerte y 4 sustracciones de menores. La Corte Suprema lo desprocesó en conformidad con la Ley de Punto Final, pero quedaron algunos procesos pendientes. En 1990 fue indultado por el presidente C. Menem. Volvió a ser detenido en el año 2003 bajo el gobierno de N. Kirchner. Está condenado hoy a prisión perpetua por crímenes de lesa humanidad. (Para más datos ver: "Represores argentinos" en http://www.desaparecidos.org/ arg/to...).

7. Los diarios señalan que estaban presentes para realizar el "escrache" a Menéndez unos quince militantes de la Federación Juvenil Comunista (FJC) y de la Juventud Intransigente (JI) además de las Madres de Plaza de Mayo. Relatan además que este pequeño grupo de manifestantes fue violentamente reprimido y que cuatro de ellos fueron detenidos mientras Menéndez se retiraba sin inconvenientes del lugar escoltado por el colectivo de la Policía Federal (Ver Clarín, La Voz, La Razón, La Nación, 22 y 23 de agosto de 1984).

8. El Daily News la publica bajo el título "Getting his point across" y señala en su epígrafe : "Body guards restrain knife- wielding retired Argentine General Luciano Menéndez as he attemps to charge group of taunting demonstrators outside a Buenos Aires TV station. Menéndez, confronted by hecklers shouting: “issasin, assasin!” has been attaked by civil rights groups as one of those responsible for stiff repression by the previous military regime, when thousands disappeared. It is charged missing were kidnaped, tortured, buried alive or pushed out of planes". (Daily News, 24 de agosto de 1984, página doble central)

9. Meses antes Menéndez ya había protagonizado un hecho similar que no tuvo la misma repercusión debido fundamentalmente a que no fue fotografiado. En enero de 1984 fue citado por la Comisión de Asuntos Constituciones del Congreso de la Nación por agraviar al Parlamento ya que había declarado en un programa en Radio Mitre que los que hablaban de "excesos en la represión [en referencia a los diputados] eran subversivos". Menéndez se presentó en el Congreso y unos manifestantes le gritaron "asesino". El diario La Nación señaló entonces: "Importantes incidentes se produjeron en la entrada del Congreso, el día que Menéndez se presentó, vestido de uniforme, a ratificar o rectificar sus declaraciones. Cuando los manifestantes le gritaban 'Asesino, asesino', Menéndez sacó una pistola 45 -que luego guardó- y declaró ante los periodistas : ‘¿no ven que todos son comunistas ?’' (La Nación, 18/1/84). (Agradezco este dato a Valentina Salvi).

10. Enrique Rosito sacó la foto que resultó más efectiva por el ángulo y la nitidez con la que se ve la actitud de Menéndez y el cuchillo. Pero había otros fotógrafos cumpliendo su labor allí también. Rosito se encargó de señalar (entonces y ahora) que hay un aspecto azaroso y fortuito en el hecho de que hubiese sido él quien tomó la imagen más lograda ya que cualquier otro compañero podría haberla obtenido.

11. El premio Rey de España a la mejor fotografía periodística es entregado por la Agencia EFE y la Agencia Española de Cooperación Internacional. Fue creado en 1983 y es el premio a la fotografía de prensa más prestigioso de Iberoamérica.

12. Esta política de ocultamiento, especialmente a través de la desaparición forzada de personas, fue acompañada simultáneamente de una política de visibilidad y producción de imágenes. Se diseñaron desde el poder estrategias de persuasión, discursos, valores y creencias para instalar una imagen de "rostro humano" de los hacedores del golpe. Para ver un estudio sobre este tema : Gamarnik, 2011.

13. Para un estudio sobre las fotografías rescatadas de los centros clandestinos ver: Feld, 2013 ; Feld, 2014 ; Longoni y García, 2013. 
14. Para este autor, la fuerza de la fotografía reside en poder dar testimonio, ser testigo, pero no de un objeto sino del tiempo (Barthes, 2008 : 137).

15. Según señala Claudia Feld el "show del horror" era un "fenómeno de ribetes desinformantes" basado en información "redundante, macabra e hiperrealista de los descubrimientos de fosas anónimas" que producía en el público "la saturación y el horror sostenido" (Landi y González Bombal, 1995 : 156, citado en Feld, 2014 : 37).

16. La Acordada número 14 dada a conocer el 27 de marzo de 1985 por la Cámara Federal reglamentaba el uso del espacio, la composición y magnitud del público que asistiría, el comportamiento de los asistentes durante las audiencias y su difusión (Feld, 2002 : 17).

17. Para un estudio profundo y exhaustivo sobre la filmación y televisación de las imágenes del Juicio a las Juntas ver Feld 2002.

18. Dicha foto también fue elegida como contratapa del libro "En negro y blanco. Fotografías del Cordobazo al Juicio a las Juntas", una compilación realizada por Pablo Cerolini y Alejandro Reynoso en el año 2006, crucial para la historia de la fotografía periodística argentina.

\section{RESÚMENES}

El inicio de la democracia en 1983 significó una bisagra en la historia argentina reciente. Desde el desarrollo de las elecciones en octubre de ese año, y durante 1984 y 1985, se sucedieron acontecimientos de gran relevancia para el país. Mientras la corporación militar buscó condicionar a la naciente democracia, algunos fotógrafos y algunas fotografías tuvieron un protagonismo particular para señalar el peligro que aún representaba el pasado autoritario. Este trabajo recorre la historia de dos de estas imágenes que actuaron como "acontecimientos visuales" y "constatación" de los hechos frente al ocultamiento y al "show del horror" que se instalaron desde algunas superficies mediáticas.

The beginning of democracy in 1983 marked a turning point in the recent history of Argentina. Since the conduct of elections in October of that year, and during 1984 and 1985, events of major importance for the country followed. While the military corporation sought to restrain the nascent democracy, some photographers and some photographs had a particular role to point out the danger that the authoritarian past still represented. This paper traces the history of two of these images that acted as 'visual events' and 'checking' of the facts against the concealment and the "horror show " which were set from some media surfaces.

\section{ÍNDICE}

Keywords: postdictatorship, democracy, photojournalism, press photos, visibility

Palabras claves: postdictadura, democracia, fotoperiodismo, fotografías de prensa, visibilidad

\section{AUTOR}

CORA GAMARNIK

FSOC / UBA / UNM 